\title{
Antimicrobial Diterpene from the Brazilian Termite Nasutitermes macrocephalus (Isoptera: Termitidae: Natutitermitinae)
}

\author{
Márcia N. S. de la Cruz, ${ }^{a}$ Helvécio M. dos Santos Júnior, ${ }^{a}$ Denilson F. Oliveira ${ }^{b}$ and \\ Claudia M. Rezende*,a
}

\author{
${ }^{a}$ Instituto de Química, Universidade Federal do Rio de Janeiro, 21941-909 Rio de Janeiro-RJ, Brazil \\ ${ }^{b}$ Departamento de Química, Universidade Federal de Lavras, 37200-000 Lavras-MG, Brazil
}

\begin{abstract}
Termites are insects with a complex social organization on castes among which soldiers are the only responsible for the colony defense. The soldiers of the Nasutitermes genus use chemical defense, which comprises a mixture of mono, sesqui and mainly diterpenes. The new diterpene 2 $\beta, 3 \alpha$-dihydroxy-trinervita-1(15),11-diene, found in Nasutitermes macrocephalus, was isolated using preparative high performance liquid chromatography (HPLC) and identified by gas chromatography-mass spectrometry (GC-MS) and nuclear magnetic resonance (NMR) techniques. The absolute stereochemistry determined was supported by ab initio calculations and by comparison of the experimental circular dichroism data with the theoretical results. The isolated diterpene was evaluated against the bacteria Staphylococcus aureus (Gram-positive) and Escherichia coli (Gram-negative), and the fungi Candida albicans and Aspergillus brasiliensis. The isolated diterpene presented minimal inhibitory concentrations of 62.5 and $62.5 \mu \mathrm{g} \mathrm{mL}{ }^{-1}$ against S. aureus and C. albicans, respectively.
\end{abstract}

Keywords: Nasutitermes macrocephalus, biological activities, HPLC

\section{Introduction}

Termites are insects present all over the world, with about 2750 species living in tropical and subtropical regions. ${ }^{1}$ They are social insects with castes responsible for distinct functions: workers are tasked to build the mound and to feed the others castes; king and queen respond for reproduction, resulting in eggs that become larvae that may become workers, soldiers or winged (secondary breeding). ${ }^{2,3}$ Soldiers are responsible for the defense of the mound and, depending on the species they will present mechanical and/or chemical defense. ${ }^{1,2,4,5}$ The Nasutitermes genus (Isoptera: Termitidae: Nasutitermitinae) is the most evolved among the termites since their soldiers use only chemical defense, avoiding contact with the enemies. ${ }^{5}$ They produce and storage a mixture of mono, sesqui and diterpenes in the frontal gland, resulting in a sticky secretion that is ejected against the enemies. ${ }^{6-10}$ The great success of the Nasutitermes evolution has been attributed to this defense method. ${ }^{2}$ The monoterpenes are the same compounds found in plants, like $\alpha$-pinene, $\beta$-pinene,

*e-mail: claudia.rezendeufrj@gmail.com limonene and terpinolene, and they are associated with the protection of the colony from fungal infections. ${ }^{11}$ Sesquiterpenes are in minor quantity, as found in $N$. gracilirostris, $N$. torresi, $N$. triodiae, $N$. octopilis and $N$. macrocephalus. ${ }^{9,12,13}$ The skeletons of the diterpenes found in termites (trinervitanes, kempanes and rippertanes) are broadly described in all species, ${ }^{14}$ and are related to both species communication, as they are blind, and to defense. ${ }^{15}$ Although there are several studies on the identification of these diterpenes, just a few of them focused on the biological activities of those substances. For example, one study presented five compounds with antibacterial activity against Bacillus subtilis and Escherichia coli. ${ }^{16}$ Therefore, several molecules with interesting biological activities produced by species in the Nasutitermes genus, remains to be studied.

As a consequence, our research group recently studied the biological activities and chemical composition of the crude extract from $N$. macrocephalus soldiers, which inhibited the growth of methicillin resistant Staphylococcus aureus and Candida albicans. ${ }^{13}$ To continue this study, the crude extract was further fractionated to obtain a new substance that was fully characterized by 
spectrometric methods and underwent antibacterial and antifungal assays to evaluate its biological activities.

\section{Experimental}

\section{General experimental procedures}

Optical rotation was measured in a PerkinElmer 341 LC polarimeter. Electronic circular dichroism (ECD) spectrum was obtained in a JASCO, J-715, Circular Dichroism (CD) Spectropolarimeter, using acetonitrile as solvent. $1 \mathrm{D}$ and 2D nuclear magnetic resonance (NMR) spectra were recorded in a Bruker Ultrafield Avance $600 \mathrm{MHz}$ or $400 \mathrm{MHz}$ spectrometer, with $\mathrm{CDCl}_{3}$ as solvent. EIMS analysis were performed in an HP GC-EIMS (gas chromatography with electron ionization mass spectrometry) (mass selective detector model 5937 and GC model G1530A) (70 eV) spectrometer with a HP-5 column $(30 \mathrm{~m} \times 250 \mu \mathrm{m} \times 0.25 \mu \mathrm{m})$. The HRESIMS (high-resolution electrospray ionization mass spectrometry) spectra in a positive mode were recorded in a Waters QTOF Micro mass spectrometer with direct infusion on the ionization source. Fractionation and isolation were performed in a preparative high performance liquid chromatograph (HPLC) Shimadzu Prominence 20A system with a Phenomenex Gemini C-18 preparative column $(21.2 \times 250 \mathrm{~mm}, 5 \mu \mathrm{m})$.

\section{Termite material}

The mound was collected at Fiocruz campus

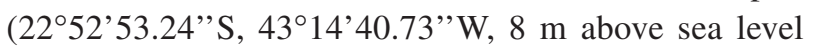
(ASL), Rio de Janeiro, RJ, Brazil) from a Leucaena sp. Benth. tree and identified as Nasutitermes macrocephalus (Isoptera: Termitidae: Nasutitermitinae) by Dsc Maurício Rocha from University of São Paulo (USP) Museum, where a specimen has been deposited (MZUSP 15803).

\section{Extraction, GC-EIMS analysis, and isolation}

Soldiers (21.5 g) of $N$. macrocephalus were separated from the other castes and crushed in $\mathrm{CH}_{2} \mathrm{Cl}_{2}$ at room temperature for $5 \mathrm{~min}$. The resulting mixture was filtered and dried under a nitrogen flow to yield $824.2 \mathrm{mg}$ of a crude extract. An aliquot of this material $\left(1 \mathrm{mg} \mathrm{mL}^{-1}\right.$ in $\mathrm{CH}_{2} \mathrm{Cl}_{2}$ ) was analyzed by GC-EIMS, with the injector set at $280{ }^{\circ} \mathrm{C}$, detector at $290^{\circ} \mathrm{C}$, injection volume of $1 \mu \mathrm{L}$, and nitrogen as gas carrier at $1.2 \mathrm{~mL} \mathrm{~min}{ }^{-1}$. The temperature was initially maintained at $45^{\circ} \mathrm{C}$ for $5 \mathrm{~min}$, and then raised to $130{ }^{\circ} \mathrm{C}$ at a rate of $12{ }^{\circ} \mathrm{C} \mathrm{min}^{-1}$. From 130 to $230{ }^{\circ} \mathrm{C}$ and from 230 to $290{ }^{\circ} \mathrm{C}$, the temperature was raised at rates of 33 and $1.5^{\circ} \mathrm{C} \mathrm{min}^{-1}$, respectively. The total time of analysis amounted to $60.0 \mathrm{~min}$. Part of the $\mathrm{CH}_{2} \mathrm{Cl}_{2}$ extract $(602.7 \mathrm{mg})$ was dissolved in methanol (12 mL, $\left.50.2 \mathrm{mg} \mathrm{mL}^{-1}\right)$ and fractionated (volume of each injection: $800 \mu \mathrm{L}$ ) on an HPLC system using $\mathrm{CH}_{3} \mathrm{CN}: \mathrm{H}_{2} \mathrm{O}(75: 25)$ at flow ratio of $20 \mathrm{~mL} \mathrm{~min}^{-1}$ as mobile phase. The process was monitored at $\lambda 210 \mathrm{~nm}$ for $55.0 \mathrm{~min}$ to select the fractions to be collected, which were dried under reduced pressure. The fraction with the isolated diterpene (14.5 min) yielded $10.0 \mathrm{mg}$.

\section{Antimicrobial assays}

Both the $\mathrm{CH}_{2} \mathrm{Cl}_{2}$ extract and the isolated substance underwent broth microdilution assays to determine their MIC (minimal inhibitory concentration) values. ${ }^{17}$ Briefly, after two-fold serial dilution of test samples, the wells were inoculated with $10 \mu \mathrm{L}$ of a bacterial suspension of $E$. coli ATCC 8739 or methicilin-resistant S. aureus BMB 9393 (MRSA) in Müeller-Hinton, or inoculated with $100 \mu \mathrm{L}$ of RPMI-MOPS pH 7.2 containing C. albicans ATCC 10231 or A. brasiliensis ATCC 16404. The microplates were incubated overnight at $37^{\circ} \mathrm{C}$ for MRSA and for $48 \mathrm{~h}$ at room temperature $\left(28-30{ }^{\circ} \mathrm{C}\right)$ for fungi. The negative control was pure medium, and positive controls comprised inoculated growth medium. The results were based on visual growth of microorganisms. The lowest concentrations of the samples that inhibited the growth of microorganisms were considered their MIC values. The visual observations were confirmed after aseptically addition of resazurin $(30 \mu \mathrm{L})$ to the microplate wells, followed by incubation at $37^{\circ} \mathrm{C}$ for $1 \mathrm{~h}$.

\section{Computational methods}

Initially, the isolated substance underwent a conformational search using the software Open3Dalign 2.103. ${ }^{18}$ One thousand molecular dynamics simulations were carried out for the substance at 1,000 K, with a $1 \mathrm{fs}$ time step for $1 \mathrm{ps}$ using the MMFF94 force field, and considering the solvent (water) implicitly using the GBSA model. The most stable conformation in each simulation was optimized with the MMFF94S force field and ranked according to the final energy. The most stable conformation and those up to $10 \mathrm{kcal} \mathrm{mol}^{-1}$ from the most stable underwent optimization with the Hamiltonian PM $7{ }^{19}$ using the software MOPAC 2012. ${ }^{20,21}$ In this step the solvent (acetonitrile, dielectric constant $=37.5$ ) was implicitly considered using the conductor-like screening model (COSMO). The most stable conformation and those up to $10 \mathrm{~kJ} \mathrm{~mol}^{-1}$ distant from the most stable were optimized in a density functional theory (DFT) calculation at the B3LYP/Def2-TZVP-RIJCOSX ${ }^{22-27}$ level of theory using the software ORCA $2.9 .{ }^{28} \mathrm{COSMO}$ was also used 
in this calculation to consider the solvent (acetonitrile) implicitly. As no conformation could be found up to $20 \mathrm{~kJ} \mathrm{~mol}^{-1}$ from the most stable, only one was used in the next step that comprised time-dependent density functional theory (TD-DFT) calculation at the same level of theory. A total of 20 excited states were calculated, and only singlet excited states were considered. The DFT optimization of the conformations and TD-DFT calculation were also performed at the B3LYP/6-311G (2d,2p) ${ }^{29}$ level of theory. Rotational and oscillator strengths were respectively converted into CD and UV (ultraviolet) spectra using the software SPECDIS 1.51.30 These conversions were carried out employing Gaussian curves with half the bandwidth of the CD band at $1 / \mathrm{e}$ peak height $(\sigma)$ equal to $0.29 \mathrm{eV}$.

\section{$2 \beta, 3 \alpha$-Dihydroxytrinervita-1(15),11-diene}

White resin $(10.0 \mathrm{mg}) ;[\alpha]_{\mathrm{D}}{ }^{20}-5.0\left(c 0.046 \mathrm{CHCl}_{3}\right) ; \mathrm{CD}$ (0.33 mM, $\left.\mathrm{CH}_{3} \mathrm{CN}\right) \lambda_{\max } / \mathrm{nm}(\Delta \varepsilon): 200$ (14.3), $220(-15.8)$, 240 (-0.3); EIMS (70 eV) m/z: 304 [M+· (1), 286 (13), 271 (19), 255 (6), 215 (4), 207 (13), 201 (5), 190 (8), 175 (19), 159 (11), 147 (12), 135 (40), 119 (27), 107 (29), 91 (30), 79 (21), 67 (22), 55 (26), 44 (100). HRESIMS, ESI (+): $m / z[\mathrm{M}+\mathrm{H}]^{+} 305.2472$ (calcd. for $\mathrm{C}_{20} \mathrm{H}_{33} \mathrm{O}_{2}{ }^{+} 305.2475$ ).

\section{Results and Discussion}

According to Everaerts et al. ${ }^{9}$ and Braekman et al., ${ }^{31}$ there is no difference in the final results of diterpene composition when crushing just the heads or the entire bodies of the termites. Therefore, the entire bodies of $N$. macrocephalus soldiers were employed in the present study to obtain larger mass of extracted substances. Fractionation of the $\mathrm{CH}_{2} \mathrm{Cl}_{2}$ extract yielded $10 \mathrm{mg}$ of a white resin whose molecular formula $\left(\mathrm{C}_{20} \mathrm{H}_{32} \mathrm{O}_{2}\right)$ was determined through HRESIMS by the protonated molecule at $m / z 305.2472[\mathrm{M}+\mathrm{H}]^{+}$.

The structure elucidation (relative stereochemistry) of the isolated compound was carried out using $1 \mathrm{D}\left({ }^{1} \mathrm{H},{ }^{13} \mathrm{C}\right)$ and 2D (HSQC (heteronuclear single quantum correlation) $\left({ }^{1} J_{\mathrm{HC}}\right), \mathrm{HMBC}$ (heteronuclear multiple bond correlation) $\left({ }^{2,3} J_{\mathrm{HC}}\right), \mathrm{COSY}$ (correlation spectroscopy) and NOESY (nuclear Overhauser effect spectroscopy)) NMR techniques (Table 1). Chemical shifts are given in parts per million (ppm). On the basis of ${ }^{13} \mathrm{C}$ NMR data, 20 resonances were assigned to four methyl groups $(\delta 22.0,21.3,18.1$ and 16.4), six methylenes $(\delta 37.8,28.6,40.3,24.6,38.4$ and 28.0), six methines $(\delta 76.9,78.8,48.8,30.5,129.6$ and 61.8$)$, and four quaternary carbons ( $\delta 130.8,44.7,131.3$ and 130.4). The ${ }^{1} \mathrm{H}$ NMR spectrum showed signals consistent with the presence of four methyls at $\delta_{\mathrm{H}} 1.55\left(\mathrm{~d}, J 1.9 \mathrm{~Hz}, \mathrm{CH}_{3}-17\right)$, $0.96\left(\mathrm{CH}_{3}-18\right), 0.84$ (d, J $\left.6.8 \mathrm{~Hz}, \mathrm{CH}_{3}-19\right)$, and 1.66 (d,
$J 1.3 \mathrm{~Hz}, \mathrm{CH}_{3}-20$ ), the first one and the last being allylic methyls, the second is bonded to a quaternary carbon, and the third bonded to a tertiary carbon.

Table 1. ${ }^{1} \mathrm{H}$ and ${ }^{13} \mathrm{C}$ NMR data for $2 \beta, 3 \alpha$-dihydroxytrinervita$1(15), 11$-diene and their correlation by HSQC $\left({ }^{1} J_{\mathrm{HC}}\right)$

\begin{tabular}{|c|c|c|}
\hline Position & ${ }^{13} \mathrm{C} \mathrm{NMR}$ & HSQC \\
\hline $\mathrm{C}$ & $\delta_{\mathrm{C}} / \mathrm{ppm}$ & $\delta_{\mathrm{H}} / \mathrm{ppm}$ \\
\hline 1 & 130.8 & - \\
\hline 2 & 76.9 & $4.03(1 \mathrm{H}, \mathrm{d}, J 8.7 \mathrm{~Hz})$ \\
\hline 3 & 78.8 & $3.71(1 \mathrm{H}, \mathrm{d}, J 8.7 \mathrm{~Hz})$ \\
\hline 4 & 44.7 & - \\
\hline 5 & 37.8 & $\begin{array}{l}1.44(1 \mathrm{Ha}, \mathrm{m}) \\
1.67(1 \mathrm{Hb}, \mathrm{m})\end{array}$ \\
\hline 6 & 28.6 & $\begin{array}{l}1.62(1 \mathrm{Ha}, \mathrm{m}) \\
1.82(1 \mathrm{Hb}, \mathrm{m})\end{array}$ \\
\hline 7 & 48.8 & $1.88(1 \mathrm{H}, \mathrm{m})$ \\
\hline 8 & 30.5 & $1.60(1 \mathrm{H}, \mathrm{m})$ \\
\hline 9 & 40.3 & $\begin{array}{l}1.09(1 \mathrm{H}, \mathrm{m}) \\
1.25(1 \mathrm{H}, \mathrm{m})\end{array}$ \\
\hline 10 & 24.6 & $\begin{array}{c}1.75(1 \mathrm{H}, \mathrm{m}) \\
2.13(1 \mathrm{Ha}, \mathrm{m})\end{array}$ \\
\hline 11 & 129.6 & $5.28(1 \mathrm{H}, \mathrm{dd}, J 5.0 / 5.8 \mathrm{~Hz})$ \\
\hline 12 & 131.3 & - \\
\hline 13 & 38.4 & $\begin{array}{l}2.10(1 \mathrm{Ha}, \mathrm{m}) \\
2.53(1 \mathrm{Hb}, \mathrm{m})\end{array}$ \\
\hline 14 & 28.0 & $\begin{array}{l}2.13(1 \mathrm{Ha}, \mathrm{m}) \\
2.42(1 \mathrm{Hb}, \mathrm{m})\end{array}$ \\
\hline 15 & 130.4 & - \\
\hline 16 & 61.8 & $2.13(1 \mathrm{H}, \mathrm{d}, J 7.3 \mathrm{~Hz})$ \\
\hline 17 & 22.0 & $1.55(3 \mathrm{H}, \mathrm{d}, J 1.9 \mathrm{~Hz})$ \\
\hline 18 & 21.3 & $0.96(3 \mathrm{H}, \mathrm{s})$ \\
\hline 19 & 18.1 & $0.84(3 \mathrm{H}, \mathrm{d}, J 6.8 \mathrm{~Hz})$ \\
\hline 20 & 16.4 & $1.66(3 \mathrm{H}, \mathrm{d}, J 1.3 \mathrm{~Hz})$ \\
\hline
\end{tabular}

The coupling of a methyl group $\left(\mathrm{C}-18, \delta_{\mathrm{H}} 0.96\right)$ bonded to a tertiary carbon bearing a proton with a signal at $\delta_{\mathrm{H}} 1.60$ (H-8), with which the methyl protons were coupled with constant of $6.8 \mathrm{~Hz}$, was confirmed in the COSY experiment $\left({ }^{3} J_{\mathrm{HH}}\right)$. The signal associated with the methine double bond proton at $\delta_{\mathrm{H}} 5.28(\mathrm{dd}, J 5.0 / 5.8 \mathrm{~Hz} \mathrm{H}-11)$, connected to C-11 ( $\delta$ c 129.6) according to the HSQC experiment, was coupling to C-9 $\left(\delta_{\mathrm{C}} 40.3,{ }^{3} J_{\mathrm{CH}}\right), \mathrm{C}-10\left(\delta_{\mathrm{C}} 24.6,{ }^{2} J_{\mathrm{CH}}\right), \mathrm{C}-13$ $\left(\delta_{\mathrm{C}} 38.4,{ }^{3} J_{\mathrm{CH}}\right)$, and $\mathrm{C}-20\left(\delta_{\mathrm{C}} 16.4,{ }^{3} J_{\mathrm{CH}}\right)$, according to the HMBC experiment. This result was important to confirm the ${ }^{1} \mathrm{H}$ and ${ }^{13} \mathrm{C}$ chemical shifts attributed to these groups. Although the methine proton at $\delta_{\mathrm{H}} 1.88(\mathrm{H}-7)$ showed a multiplet, the methine proton at $\delta_{\mathrm{H}} 2.13(\mathrm{H}-16)$ exhibited a doublet with a constant of $7.3 \mathrm{~Hz}$. The coupling of these hydrogens was also confirmed in the COSY $\left({ }^{3} J_{\mathrm{HH}}\right)$ spectrum. The carbinolic protons presented a coupling 
constant of $8.7 \mathrm{~Hz}$, that is characteristic of $\mathrm{H}_{\text {axial }}-\mathrm{H}_{\text {axial }}$ coupling in a saturated six members ring. This corroborates the trans relationship between the hydroxyl groups. NOE correlations observed through the NOESY spectrum show interactions of H-3 with H-6a and H-14a (both up), confirming the relative configurations of both $\mathrm{C}-3$ and C-8 (both hydroxyl and methyl groups in axial position). H-2 correlations with $\mathrm{H}-16$ and $\mathrm{H}-18$ in the NOESY spectrum also confirmed the relative configurations of C-2, C-16 and C-18 (Figure 1). NOESY spectrum also shows interaction of $\mathrm{H}-8$ with $\mathrm{H}-16$, also confirming the configurations of C-8 and C-16. In conclusion, interpretation of the NMR data leads to the structure $2 \beta, 3 \alpha$-dihydroxy-trinervita1(15),11-diene, which is a new diterpene (Figure 1).

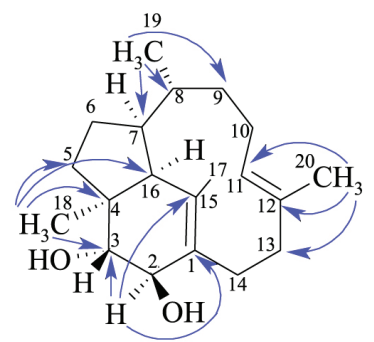

(a)

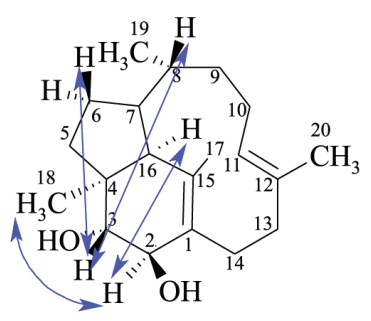

(b)

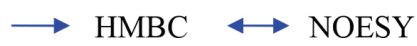

Figure 1. (a) Key ${ }^{1} \mathrm{H}_{-}{ }^{13} \mathrm{C}$ couplings at two and three bonds distant (HMBC, ${ }^{2,3} J_{\mathrm{HC}}$ ) of $2 \beta, 3 \alpha$-dihydroxy-trinervita-1(15),11-diene and (b) key NOE correlations (NOESY).

There was no doubt about the relative configuration of the isolated substance. Therefore, aiming to discover its absolute configuration by comparing its experimental and theoretical ECD spectra (Figure 2), a conformational search was performed using molecular mechanics methods, which afforded eight conformations. The energy difference between the most and the less stable was $8.8046 \mathrm{kcal} \mathrm{mol}^{-1}$. When all these conformations underwent optimization through semiempirical calculations only four of them presented total energies corresponding to above $1 \%$ of the Boltzmann distribution. Therefore, only these four conformations were further optimized through DFT calculations, according to which one had energy corresponding to more than $99 \%$ of the Boltzmann distribution at both levels of theory employed.

The root-mean-square deviation between atomic positions of superimposed conformations resulting from both DFT calculations, accounting to more than $99 \%$ of the Boltzmann distribution, was only $0.074 \AA$. Thus, these conformations are practically the same and are in agreement with the NMR data. For example, in the conformation obtained at the B3LYP/Def2-TZVP/RIJCOSX level of theory, the distance between H-3 with H-6a is $1.942 \AA$,

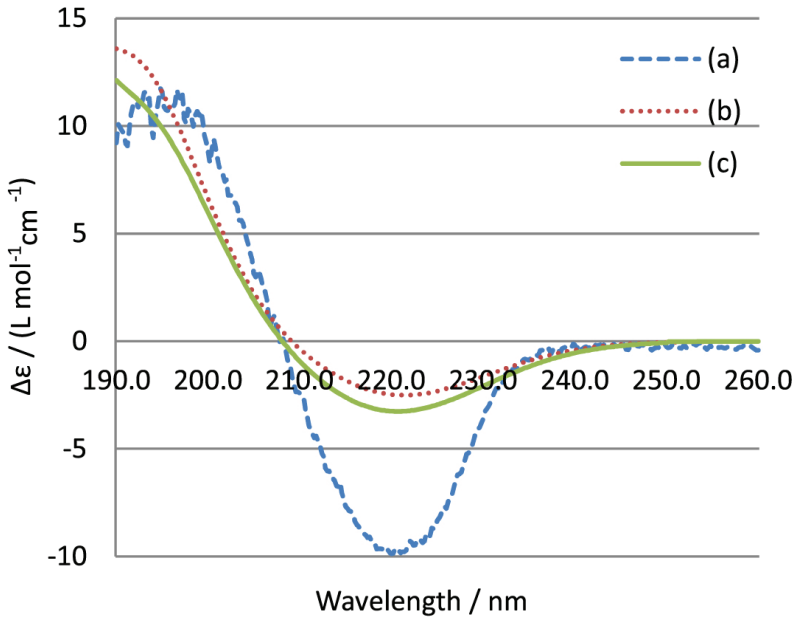

Figure 2. Experimental (a) and theoretical electronic circular dichroism spectra for $2 \beta, 3 \alpha$-dihydroxy-trinervita-1(15),11-diene. The theoretical spectra were obtained through time-dependent density functional theory at two levels: B3LYP/Def2-TZVP-RIJCOSX (b) and B3LYP/6-311G-2d2p (c).

while between $\mathrm{H}-3$ and $\mathrm{H} 8$ is $2.761 \AA$. Regarding $\mathrm{H}-2$, its distances from $\mathrm{H}-16$ and $\mathrm{H}-18$ are 3.917 and $2.274 \AA$, respectively (Figure 3 ). All these values are in accordance with the observed NOE.

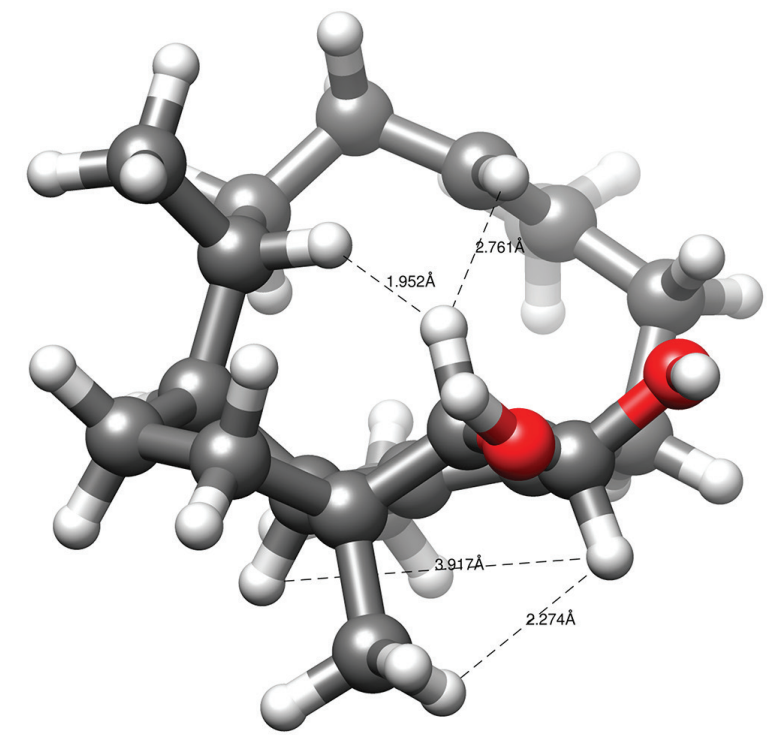

Figure 3. Three-dimensional structure of the most stable conformation of the isolated substances, according to density functional theory calculations carried out at the B3LYP/Def2-TZVP/RIJCOSX level of theory.

Both theoretical ECD spectra, obtained through TD-DFT calculations at both levels of theory for the isolated substance, were in accordance with the experimental one, suggesting that the attributed configuration was correct. Based on the data described, the configuration of the substance was established as $(2 R, 3 R, 4 S, 7 S, 8 R, 11 E, 16 S)$ 2,3-dihydroxytrinervita-1(15),11-diene. 
The isolated compound was evaluated against a series of fungal and bacterial strains. The bacteria methicillinresistant Staphylococcus aureus BMB 9393 (clinical isolate) (MRSA) and Escherichia coli ATCC 8739 were chosen for antibacterial assay due to the association with hospital acquired infections worldwide and gastrointestinal infections, respectively. ${ }^{32}$ Candida albicans ATCC 10231 and Aspergillus brasiliensis ATCC 16404 were used in the antifungal assay, since they are responsible for candidiasis and lung infections, respectively. ${ }^{33}$ The isolated diterpene showed activity against both MRSA (MIC $=62.5 \mu \mathrm{g} \mathrm{mL}^{-1}$ ) and $C$. albicans ( $\mathrm{MIC}=62.5 \mu \mathrm{g} \mathrm{mL} \mathrm{m}^{-1}$ ), and no activity against the Gram-negative bacterium E. coli was observed. It was also inactive against the filamentous fungus A. brasiliensis. The positive controls ciprofloxacin and amphotericin B presented MIC values of 0.5 and $0.125 \mu \mathrm{g} \mathrm{mL} \mathrm{m}^{-1}$, for antibacterial and antifungal activity, respectively. This result contributes to know the role of diterpenes produced by the termites, and help to understand the chemical ecology of termites.

\section{Conclusions}

In this study a diterpene trinervitene was isolated from termite soldiers of Nasutitermes microcephalus and presented antimicrobial activities against $S$. aureus and C. albicans.

This work contributes to the knowledge of termite chemical composition, which is fundamental to understand the success of termites development and adaptation to many different environments.

\section{Supplementary Information}

Supplementary data (chromatogram, mass spectrum, ${ }^{1} \mathrm{H}$ and ${ }^{13} \mathrm{C}$ NMR spectra, COSY, HSQC, HMBC correlation maps, and results through molecular mechanics) are available free of charge at http://jbcs.sbq.org.br as PDF file.

\section{Acknowledgments}

The authors would like to thank the DIRAC/Fiocruz, Dr Mauricio Rocha of the University of São Paulo Museum, Dr Antonio Gilberto Ferreira of the University of São Carlos, Dr Daniela S. Alviano of Federal University of Rio de Janeiro, and Centro Nacional de Supercomputação (CESUP) from Federal University of Rio Grande do Sul (UFRGS) where part of the computational work was carried out. We also thank CNPq (Conselho Nacional de Desenvolvimento Científico e Tecnológico), CAPES (Coordenação de Aperfeiçoamento de Pessoal de Nível
Superior), FAPERJ (Fundação Carlos Chagas Filho de Amparo à Pesquisa do Estado do Rio de Janeiro) and FAPEMIG (Fundação de Amparo à Pesquisa do Estado de Minas Gerais), for financial support and fellowships.

\section{References}

1. Constantino, R.; Pap. Avulsos Zool. 1999, 40, 387.

2. Prestwich, G.; Sci. Am. 1983, 249, 68.

3. Laurent, P.; Daloze, D.; Pasteels, J. M.; Braekman, J. C.; J. Nat. Prod. 2005, 68, 532.

4. Prestwich, G.; Biochem. Syst. Ecol. 1979, 7, 211.

5. Prestwich, G.; Annu. Rev. Entomol. 1984, 29, 201.

6. Baker, R.; Walmsley, S.; Tetrahedron 1982, 38, 1899.

7. Prestwich, G.; Solheim, B.; Clardy, J.; Pilkiewicz, F.; Miura, I.; Tanis, S.; Nakanishi, K.; J. Am. Chem. Soc. 1977, 99, 8082.

8. Prestwich, G.; J. Chem. Ecol. 1979, 5, 459.

9. Everaerts, C.; Roisin, Y.; Le Quéré, J.-L.; Bonnard, O.; Pasteels, J.; J. Chem. Ecol. 1993, 19, 2865.

10. Prestwich, G.; Tetrahedron 1982, 38, 1911.

11. Rosengaus, R.; Lefebvre, M.; Traniello, J.; J. Chem. Ecol. 2000, 26, 21.

12. Prestwich, G.; Collins, M.; Biochem. Syst. Ecol. 1981, 9, 83.

13. Cruz, M. N. S.; Júnior, H. M. S.; Oliveira, D. F.; Costa-Lotufo, L. V.; Ferreira, A. G.; Alviano, D. S.; Rezende, C. M.; Nat. Prod. Commun. 2013, 8, 69.

14. Cruz, M. N. S.; Júnior, H. M. S.; Rezende, C. M.; Alves, R. J. V.; Cancello, E. M.; Rocha, M. M.; Quim. Nova 2014, 37, 95.

15. Budesinsky, M.; Valterova, I.; Sémon, E.; Cancello, E.; Bordereau, C.; Tetrahedron 2005, 61, 10699.

16. Zhao, C.; Rickards, R.; Trowel, S.; Tetrahedron 2004, 60, 10753.

17. Clinical and Laboratory Standards Institute (CLSI); M27-A3, Reference Method for Broth Dilution Antifungal Susceptibility Testing of Yeasts; Approved Standard, $3^{\text {rd }}$ ed.; CLSI: Wayne, PA, USA, 2008; Clinical and Laboratory Standards Institute (CLSI); M38-A2, Reference Method for Broth Dilution Antifungal Susceptibility Testing of Filamentous Fungi; Approved Standard, $2^{\text {nd }}$ ed.; CLSI: Wayne, PA, USA, 2008; Clinical and Laboratory Standards Institute (CLSI); M7-A4, Methods for Dilution Antimicrobial Susceptibility Tests for Bacteria that Grow Aerobically, $4^{\text {th }}$ ed.; CLSI: Wayne, PA, USA, 2008.

18. Tosco, P.; Balle, T.; Shiri, F.; J. Comput.-Aided Mol. Des. 2011, 25,777 .

19. Stewart, J. J. P.; J. Mol. Model. 2013, 32, 19.

20. Stewart, J. J. P.; MOPAC2012, 13.284L Stewart Computational Chemistry: Colorado, Springs, CO, USA, 2012.

21. Maia, J. D. C.; Carvalho, G. A. U.; Júnior, C. P. M.; Santana, S. R.; Cabral, L. A. F.; Rocha, G. B.; J. Chem. Theory Comput. 2012, 8, 3072.

22. Becke, A. D. J.; J. Chem. Phys. 1993, 98, 5648. 
23. Lee, C.; Yang, W.; Parr, R. G.; Phys. Rev. B 1988, 37, 785.

24. Neese, F.; Wennmohs, F.; Hansen, A.; Becker, U.; Chem. Phys. 2009, 356, 98.

25. Weigend, F.; Ahlrichs, R.; Phys. Chem. Chem. Phys. 2005, 7 , 3297.

26. Eichkorn, K.; Weigend, F.; Treutler, O.; Ahlrichs, R.; Theor. Chem. Acc. 1997, 97, 119.

27. Eichkorn, K.; Treutler, O.; Öhm, H.; Häser, M.; Ahlrichs, R.; Chem. Phys. Lett. 1995, 240, 283.

28. Neese, F.; Wiley Interdiscip. Rev.: Comput. Mol. Sci. 2012, 2 , 73.

29. Krishnan, R.; Binkley, J. S.; Seeger, R.; Pople, J. A.; J. Chem. Phys. 1980, 72, 650.
30. Bruhn, T.; Schaumlöffel, A.; Hemberger, Y.; Bringmann, G.; Chirality 2013, 25, 243.

31. Braekman, J. C.; Daloze, D.; Dupont, A.; Pasteels, J. M.; Lefeuve, P.; Bordereau, C.; Declercq, J. P.; Van Meerssche, M.; Tetrahedron 1983, 39, 4237.

32. Ribeiro, A.; Dias, C.; Silva-Carvalho, M. C.; Berquó, L.; Ferreira, F. A.; Santos, R. N. S.; Ferreira-Carvalho, B. T.; Figueiredo, A. M.; J. Clin. Microbiol. 2005, 43, 1985.

33. Silva, A. C. R.; Lopes, P. M.; Azevedo, M. M. B.; Costa, D. C. M.; Alviano, C. S.; Alviano, D. S.; Molecules 2012, 17, 6305.

Submitted: April 10, 2017

Published online: September 14, 2017 